\title{
A study on the occurrence of Asian open bill stork, Anastomus oscitans in particular tree species at Nature Park, Kolkata, India
}

\author{
Anirban Das ${ }^{1}$, Subhodeep Sarkar ${ }^{1}$, Kushal Banerjee ${ }^{2}$, Abantika Nandy $^{2}$, \\ Soumendra Nath Talapatra ${ }^{2, *}$, Snehasikta Swarnakar ${ }^{3}$ \\ ${ }^{1}$ Department of Environmental Science, Asutosh College, \\ 92 S. P. Mukherjee Road, Kolkata - 700026, India \\ ${ }^{2}$ Department of Environmental Science, University of Calcutta, \\ 35 Ballygunge Circular Road, Kolkata - 700019, India \\ ${ }^{3}$ Drug Development Diagnostic \& Biotechnology Division, \\ CSIR - Indian Institute of Chemical Biology, 4 Raja S.C. Mullick Road, \\ Kolkata - 700032, India \\ *E-mail address: ecologylive@yahoo.co.in
}

\begin{abstract}
The trees support many bird and animal species while the survival of urban-dwelling species e.g. bird species dominate over others. This particular Nature park in Kolkata is the habitat of birds and fish species suggesting a better environment for food chain maintenance. The Asian open bill stork, Anastomus oscitans among other bird species is a common and provides ecosystem health indicator. The present study aims to understand the occurrence and population nos. of Asian open bill stork on particular tree species surrounding wetlands at Nature Park, Kolkata, India. Our results clearly indicate that a total population of this bird species having 671 nos. on the particular trees but not in all other available trees in the study area. In conclusion, present research emphasizes a novel occurrence and higher population of the A. oscitans being observed on the basis of the presence of particular tree species, though no attempt has been made on physico-chemical properties of present water and microclimate within the park. Therefore, further research planning should be oriented considering the physico-chemical impacts as well as local microenvironment along with human interaction as visitors in such a way so that these barriers cannot affect nesting and breeding of those species as eco-indicator. Also further relevant research is needed to emphasize on the conservation of these specific tree species to increase population of Asian open bill stork, A. oscitans in Nature park.
\end{abstract}

Keywords: Open bill stork; Bird population; Urban park; Bird abundance; Tree species-specific population

\section{INTRODUCTION}

Parks and gardens harbor many trees, occurring naturally and/or planted, which contribute to a number of environmental functions in urban environments, such as the survival of urban-dwelling species mainly bird species. Birds amongst other species provide a wide range of environmental and social functions to cities and urban dwellers (Orians and 
Lowenthal 1986; Costanza et al. 1997; Sanesi and Chiarello 2006; Padoa-Schioppa et al., 2007).

The Asian open bill (Anastomus oscitans) is a small, greyish-white stork, which is readily identified from other large aquatic birds in Asia by having a greyish bill with an open space between the mandibles (Robson, 2000). It is widely distributed across the Indian subcontinent and mainland Southeast Asia (Robson, 2000), with a number of breeding colonies in central Thailand (McClure, 1998), Tonle Sap Lake in Cambodia (Sun Visal and Allebone-Webb, 2009) and in U Minh Thuong National Park, southern Vietnam (Safford et al., 1998). Despite its wide distribution and the occurrence of apparently suitable habitats such as paddy fields and freshwater marshes (Wells, 1999). Asian open bills were only documented for the first time in Peninsular Malaysia in 2008 in Chuping, Perlis State (Lim et al., 2011), and increasingly regularly in Penang and Perak (e.g., Permatang Pauh) later.

The Asian Open Bill Stork (Anastomus oscitans) is found as a resident colonial breeder. It was documented that total of the nineteen species of storks found globally, in which nine species occurred in India (Ali and Ripley, 1987). The Asian Open bill is smallest and commonest of the storks among all other bird species. These birds have been recorded near the specific trees of wetlands of West Bengal, India for last 30 years. They usually migrate to North India in June and to Southern part of the country in November every year and spent about six months in this region for breeding.

Their estimated global population was 1,30,00,000 in the year 2002 (Wetland International, 2002). The species have been evaluated by IUCN as "Least Concern" (IUCN, 2013). Asian open bills prepare their nest in trees or areas that are mainly inundated with water. It has generally been accepted that the configuration and composition of vegetation of a habitat acts as one of the determining factors for the distribution and abundance of bird species (Cody, 1985). Their nest formation time and success of reproduction is also related with the rain fall of that particular area as well as availability of food resources (Dhua et al., 2013).

There are many studies that have already been conducted on bird diversity in urban habitats viz. city parks, meadow remnants, community, private gardens etc. by many research works (Newton, 1995; Navarro and Benítez, 1995; Blair, 1999; Hobson and Rempel, 2001; Turner, 2002). However, few studies have been done in Indian context in urban habitats (Tanveer et al., 2002, Sidra et al., 2013; Chowdhury et al., 2014) while very scattered research works have been found on population abundance of Asian open bill stork (Anastomus oscitans) in different places of South East Asia and especially India (Jhonson, 1992; Lim et al., 2011; Sakoot, 2012; Dhua et al., 2013; Low et al., 2013).

But no one has attempted to study the number of total population of Asian open bill stork (Anastomus oscitans) in particular tree species as their habitat at Nature Park, Kolkata, India.

The present study aims to know Asian open bill stork population nos., on particular tree species as habitat, near surrounding wetlands of measured area at Nature Park, Kolkata, India.

\section{MATERIALS AND METHODS}

The study area was selected around wetlands, where high levels of human interferences are common as visitors. The study was carried out at Nature park (latitude $=22^{\circ} 31^{\prime} \mathrm{N}$ and longitude $=88^{\circ} 17^{\prime} \mathrm{E}$ ), Kolkata, India. The field study was carried out in the month of August 2014 and September 2014 (monsoon season). 
The direct and indirect influences on bird species in this urban habitat, qualitative and quantitative assessment was done by 300 meter line transect, selected randomly within the park and evaluated the number of population in each specific tree species as well as the number of population of individual stork species. Because our sampling design involved quantifying bird species of Asian open bill stork in the field. Field survey was done by counting the species and visual identification and finally image capture in this study. The study area is depicted by a satellite image (Fig. 1).

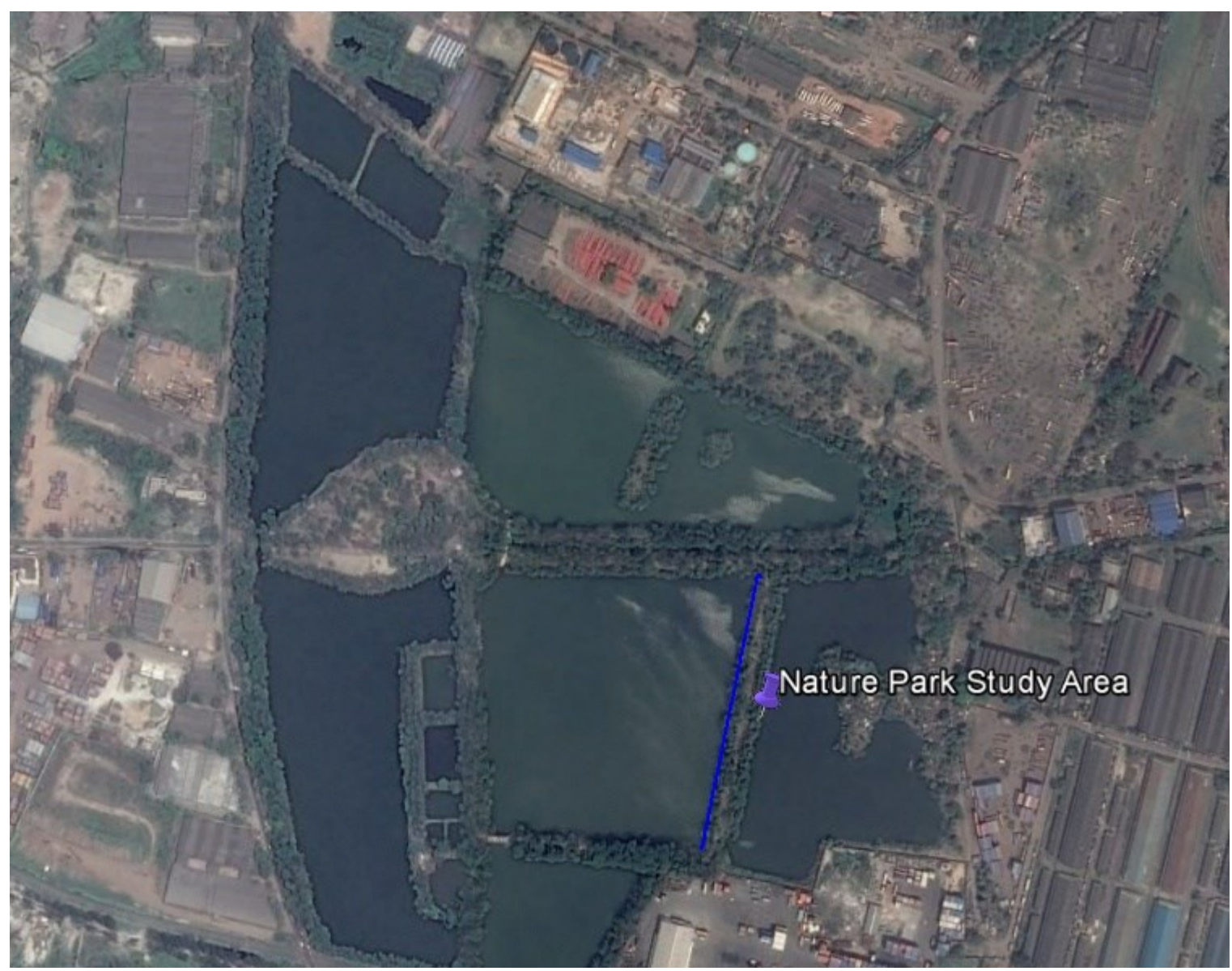

Fig. 1. Satellite image of the study area (Source: Google Earth).

Field guides methods were followed by Grimmett et al. (2001) and Mirza (2007) and were used to identify the bird species by Grimmett et al. (1998) and Tiwary (2002). The individual number and total of population in each tree species was observed and tabulated. The comparison was made on the basis of identified tree species, where nest buildings were observed and tree species without any nest buildings of Asian open bill stork.

\section{RESULTS}

The present results clearly indicate that the Asian open bill stork, Anastomus oscitans are very common and found their nests on the particular tree species at Nature Park, Kolkata inundated by wetlands (Table 1). The study of total population of individual bird species were tabulated in Table 2 and Fig. 4). The photograph of this bird species is showed in Fig. 2 and 3. 
Table 1. Study of nest building and non nest building tree species of Asian open bill stork at study area, Nature park, Kolkata, India.

\begin{tabular}{|c|c|c|}
\hline Sl. No. & Birds nest found on tree species & Birds nest not found on tree species \\
\hline 1. & Ficus religiosa (Aswatha) & Cocos nucifera (Coconut palm) \\
\hline 2. & Albizia lebbeck (Sirish) & Murraya koenigii (Curry tree) \\
\hline 3. & Anthocephalus indicus (Kadamba) & Azadirachta indica (Neem) \\
\hline 4. & Terminalia arjuna (Arjun) & Tectona grandis (Teak) \\
\hline 5. & Delonix regia (Gulmohor) & Butea monosperma (Flame of the forest) \\
\hline 6. & $\begin{array}{l}\text { Peltophorum pterocarpum } \\
\text { (Yellow Flame Tree) }\end{array}$ & $\begin{array}{c}\text { Acacia auriculiformis (Earleaf acacia / } \\
\text { Akashmoni) }\end{array}$ \\
\hline 7. & Dalbergia sisso (Seasom) & Gmelina Arborea (White teak/Gamar) \\
\hline 8. & & Tamarindus indica (Tamarind) \\
\hline 9. & & Ficus racemosa (Cluster fig/Dumur) \\
\hline 10. & & Syzygium cumini (Black plum/Jamun) \\
\hline 11. & & Pongamia pinnata (Indian Beech) \\
\hline 12. & & Grewia asiatica (Falsa) \\
\hline 13. & & Bombax malabaricum (Cotton) \\
\hline 14. & & Alstonia scholaris (Chhatim) \\
\hline 15. & & Leucaena leucocephala (Sababul) \\
\hline 16. & & Tree not identified \\
\hline 17. & & Tree not identified \\
\hline 18. & & Tree not identified \\
\hline 19. & & Tree not identified \\
\hline
\end{tabular}

The occurrence of Asian open bill stork, Anastomus oscitans species as total population of individual species were calculated and tabulated (Table 1). Interestingly, other species of bird species were observed alongwith them very rarely. The data were calculated on the basis of particular tree species. The individual and total population of bird species was observed in specific tree species. The nest building was observed only in specific tree species. Theses tree species are Ficus religiosa (Aswatha), Albizia lebbeck (Sirish), Anthocephalus indicus (Kadam), Terminalia arjuna (Arjun), Delonix regia (Gulmohor), Peltophorum pterocarpum (Yellow Flame Tree) and Dalbergia sisso (Seasom). But the nest building was not observed in other 19 varieties of tree species such as Cocos nucifera (Coconut palm), Murraya koenigii (Curry tree), Azadirachta indica (Neem), Tectona grandis (Teak), Butea monosperma (Flame of the forest), Acacia auriculiformis (Earleaf acacia / Akashmoni), Gmelina Arborea (White 
teak/Gamar), Tamarindus indica (Tamarind), Ficus racemosa (Cluster fig/Dumur), Syzygium cumini (Black plum/Jamun), Pongamia pinnata (Indian Beech), Grewia asiatica (Falsa), Bombax malabaricum (Cotton), Alstonia scholaris (Chhatim), Leucaena leucocephala (Sababul) and four species were unidentified tree species (Table 1).

Table 1 and Fig. 4 show the cumulative data of Anastomus oscitans for total population of 55 nos. in 8 trees of Ficus religiosa, 59 nos. in 15 trees of Albizia lebbeck, 15 nos. in 3 trees of Anthocephalus indicus, 16 nos. in 1 tree of Terminalia arjuna, 270 nos. in 27 trees of Delonix regia, 242 nos. in 45 trees of Peltophorum pterocarpum and 1 no in 1 tree of Dalbergia sisso respectively. Experiments were done in triplicate.

It was observed that total population was higher as 270 nos on the Delonix regia followed by 242 nos on the Peltophorum pterocarpum while lower as 1 on the Dalbergia sisso. A total population of these bird species of about 671 nos were observed in the study area of $300 \mathrm{~m}$ both sides of the internal road.

Table 2. Total population no. of individual Asian open bill stork in relation to habitat on specific tree species.

\begin{tabular}{|c|c|c|c|}
\hline Sl. No. & Tree Species & $\begin{array}{c}\text { Individual and total } \\
\text { no. of specific tree } \\
\text { species } \\
\end{array}$ & $\begin{array}{l}\text { Total population of birds in } \\
\text { each tree species }\end{array}$ \\
\hline \multirow[t]{9}{*}{1.} & Ficus religiosa (Aswatha) & 1 & 5 \\
\hline & & 2 & 18 \\
\hline & & 3 & 17 \\
\hline & & 4 & 4 \\
\hline & & 5 & 0 \\
\hline & & 6 & 6 \\
\hline & & 7 & 0 \\
\hline & & 8 & 5 \\
\hline & Total & 8 & 55 \\
\hline \multirow[t]{13}{*}{2.} & Albizia lebbeck (Sirish) & 1 & 19 \\
\hline & & 2 & 0 \\
\hline & & 3 & 23 \\
\hline & & 4 & 4 \\
\hline & & 5 & 0 \\
\hline & & 6 & 0 \\
\hline & & 7 & 7 \\
\hline & & 8 & 6 \\
\hline & & 9 & 0 \\
\hline & & 10 & 0 \\
\hline & & 11 & 0 \\
\hline & & 12 & 0 \\
\hline & & 13 & 0 \\
\hline
\end{tabular}




\begin{tabular}{|c|c|c|c|}
\hline & & 14 & 0 \\
\hline & & 15 & 0 \\
\hline & Total & 15 & 59 \\
\hline \multirow[t]{4}{*}{3.} & $\begin{array}{l}\text { Anthocephalus indicus } \\
\text { (Kadamba) }\end{array}$ & 1 & 15 \\
\hline & & 2 & 0 \\
\hline & & 3 & 0 \\
\hline & & 3 & 15 \\
\hline \multirow[t]{2}{*}{4.} & Terminalia arjuna (Arjun) & 1 & 16 \\
\hline & Total & 1 & 16 \\
\hline 5. & Delonix regia (Gulmohor) & 1 & 0 \\
\hline \multirow[t]{26}{*}{ Sl. No. } & Tree Species & $\begin{array}{c}\begin{array}{c}\text { Individual and total } \\
\text { no. of specific tree } \\
\text { species }\end{array} \\
\end{array}$ & $\begin{array}{c}\text { Total population of birds in } \\
\text { each tree species }\end{array}$ \\
\hline & & 2 & 7 \\
\hline & & 3 & 8 \\
\hline & & 4 & 22 \\
\hline & & 5 & 21 \\
\hline & & 6 & 11 \\
\hline & & 7 & 12 \\
\hline & & 8 & 0 \\
\hline & & 9 & 0 \\
\hline & & 10 & 0 \\
\hline & & 11 & 4 \\
\hline & & 12 & 5 \\
\hline & & 13 & 0 \\
\hline & & 14 & 8 \\
\hline & & 15 & 12 \\
\hline & & 16 & 13 \\
\hline & & 17 & 7 \\
\hline & & 18 & 26 \\
\hline & & 19 & 5 \\
\hline & & 20 & 9 \\
\hline & & 21 & 17 \\
\hline & & 22 & 0 \\
\hline & & 23 & 29 \\
\hline & & 24 & 44 \\
\hline & & 25 & 5 \\
\hline & & 26 & 5 \\
\hline
\end{tabular}




\begin{tabular}{|c|c|c|c|}
\hline & & 27 & 0 \\
\hline & Total & 27 & 270 \\
\hline \multirow[t]{8}{*}{6.} & $\begin{array}{c}\text { Peltophorum pterocarpum } \\
\text { (Yellow Flame Tree) }\end{array}$ & 1 & 7 \\
\hline & & 2 & 0 \\
\hline & & 3 & 0 \\
\hline & & 4 & 0 \\
\hline & & 5 & 0 \\
\hline & & 6 & 7 \\
\hline & & 7 & 0 \\
\hline & & 8 & 0 \\
\hline \multirow[t]{26}{*}{ SI. No. } & Tree Species & $\begin{array}{c}\text { Individual and total } \\
\text { no. of specific tree } \\
\text { species }\end{array}$ & $\begin{array}{c}\text { Total population of birds in } \\
\text { each tree species }\end{array}$ \\
\hline & & 9 & 0 \\
\hline & & 10 & 0 \\
\hline & & 11 & 0 \\
\hline & & 12 & 0 \\
\hline & & 13 & 0 \\
\hline & & 14 & 0 \\
\hline & & 15 & 0 \\
\hline & & 16 & 0 \\
\hline & & 17 & 1 \\
\hline & & 18 & 0 \\
\hline & & 19 & 11 \\
\hline & & 20 & 0 \\
\hline & & 21 & 0 \\
\hline & & 22 & 26 \\
\hline & & 23 & 0 \\
\hline & & 24 & 0 \\
\hline & & 25 & 0 \\
\hline & & 26 & 0 \\
\hline & & 27 & 0 \\
\hline & & 28 & 0 \\
\hline & & 29 & 0 \\
\hline & & 30 & 27 \\
\hline & & 31 & 29 \\
\hline & & 32 & 3 \\
\hline & & 33 & 9 \\
\hline
\end{tabular}




\begin{tabular}{|c|c|c|c|}
\hline & & 34 & 18 \\
\hline & & 35 & 0 \\
\hline & & 36 & 11 \\
\hline & & 37 & 0 \\
\hline & & 38 & 0 \\
\hline & & 39 & 21 \\
\hline & & 40 & 30 \\
\hline & & 41 & 0 \\
\hline & & 42 & 0 \\
\hline & & 43 & 24 \\
\hline & & 44 & 14 \\
\hline \multirow[t]{3}{*}{ Sl. No. } & Tree Species & $\begin{array}{c}\text { Individual and total } \\
\text { no. of specific tree } \\
\text { species }\end{array}$ & $\begin{array}{c}\text { Total population of birds in } \\
\text { each tree species }\end{array}$ \\
\hline & & 45 & 4 \\
\hline & Total & 45 & 242 \\
\hline \multirow[t]{2}{*}{7.} & Dalbergia sisso (Seasom) & 1 & 1 \\
\hline & Total & 1 & 1 \\
\hline
\end{tabular}

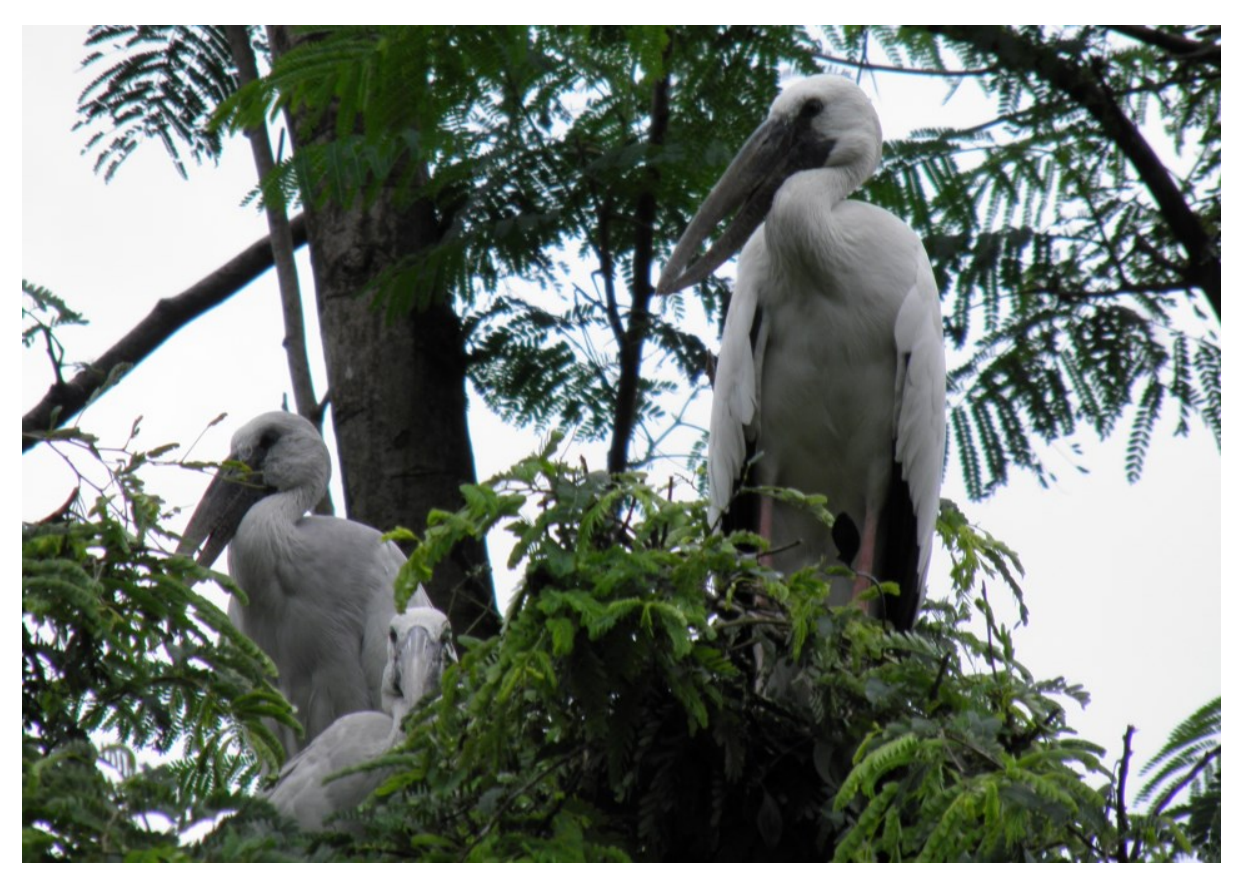

Fig. 2. Asian open bill stork, Anastomus oscitans inhabited in the study area (A group of three individual species). 


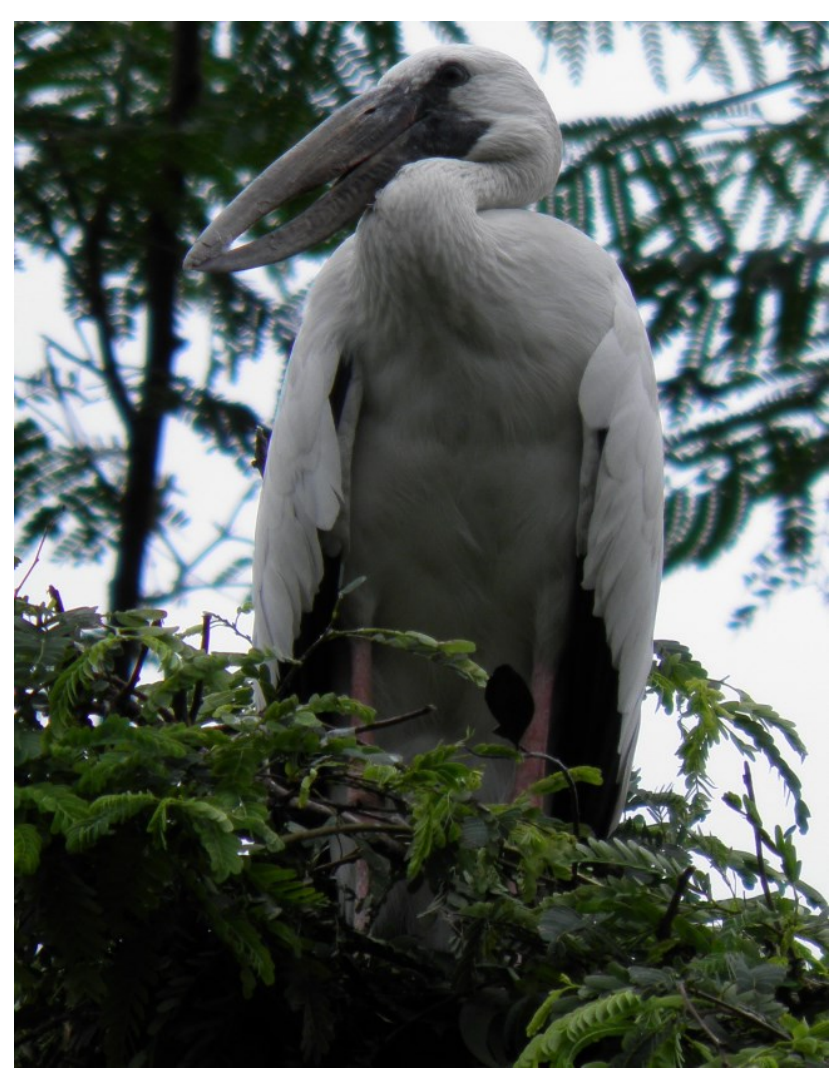

Fig. 3. Asian open bill stork, Anastomus oscitans inhabited in the study area (Closer view).

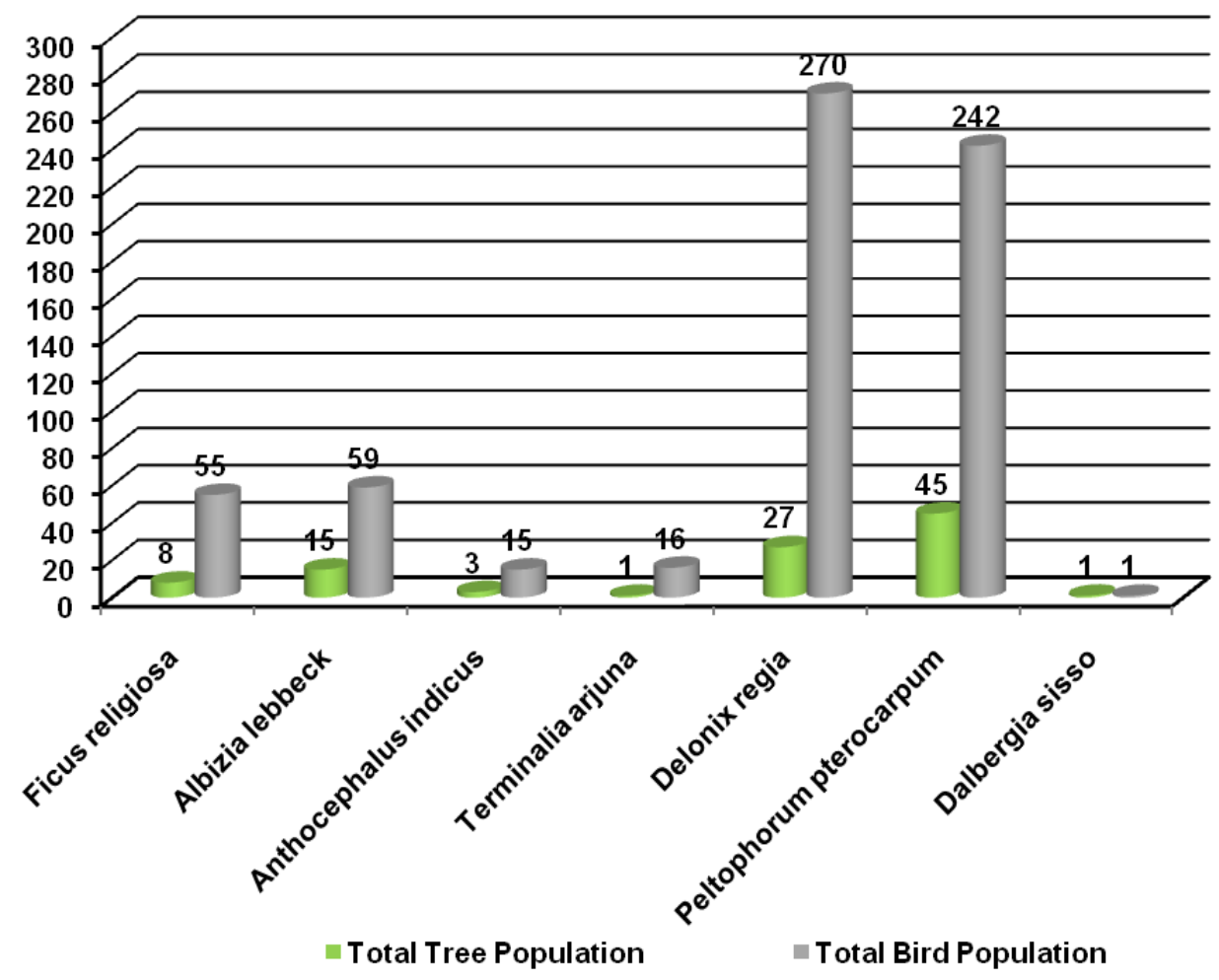

Fig. 4. Study of total population of specific tree species and total population of Asian open bill stork. 


\section{DISCUSSION}

The present study of the total population for Asian open bill stork, Anastomus oscitans reveals that the abundance is fully depend upon specific tree species, where they usually build nest and presence of their available foods in the surrounding wetlands.

Asian open bills were only documented for the first time in Peninsular Malaysia in 2008 in Chuping, Perlis State (Lim et al., 2011), and later in Penang and Perak (e.g., Permatang Pauh) with increasing frequency. This species is also widely distributed across the Indian subcontinent and mainland Southeast Asia (Robson, 2000). The Asian open bill stork (Anastomus oscitans) is found as a resident colonial breeder. It was documented that total of the nineteen species of storks found globally, in which nine species occurred in India (Ali and Ripley, 1987). The Asian open bill stork is one of the most successful large aquatic birds in Southeast Asia, and remains the most abundant stork in many places like Thailand, Malaysia, Singapore etc. However, no regular southward movements of the species from its stronghold in mainland Southeast Asia has previously been observed, with the species recorded only as a rare vagrant south of the Kra Isthmus (Wells, 1999).

In the present study area, the individual and total population of bird species was observed in specific tree species. The nest building specific tree species viz. Ficus religiosa (Aswatha), Albizia lebbeck (Sirish), Anthocephalus indicus (Kadam), Terminalia arjuna (Arjun), Delonix regia (Gulmohor), Peltophorum pterocarpum (Yellow Flame Tree) and Dalbergia sisso (Seasom) were observed. It was also observed that this bird species do not make nest or prefer all the available tree species of Nature park (Table 1), may be due to the canopy structure, flavours etc. In individual tree species and total same tree species, total population of bird species were recorded and tabulated (Table 2 and Fig. 4). A similar observation has been carried out that specific tree species are prefered for nest building of Asian open bills (Roy and Sah, 2013a).

Table 2 and Fig. 4 show the cumulative data of Anastomus oscitans for total population of 55 nos. in 8 trees of Ficus religiosa, 59 nos. in 15 trees of Albizia lebbeck, 15 nos. in 3 trees of Anthocephalus indicus, 16 nos. in 1 tree of Terminalia arjuna, 270 nos. in 27 trees of Delonix regia, 242 nos. in 45 trees of Peltophorum pterocarpum and 1 no in 1 tree of Dalbergia sisso respectively. In the present study it was observed that open bills are inhabited with a highest population on the two specific tree species namely Delonix regia and Peltophorum pterocarpum followed by Albizia lebbeck, Anthocephalus indicus, Terminalia arjuna, Ficus religiosa and Dalbergia sisso, among which some tree species are found common with the present study viz. Anthocephalus indicus, Terminalia arjuna and Dalbergia sisoo (Roy and Sah, 2013a) but some tree species were observed as new habitat.

The habitat in Asian context; it is interesting to note that the sighting of Asian open bills in Singapore is not surprising, in the reports a large numbers of the species in Peninsular Malaysia in recent weeks, and large flocks seen over Chumphon Province, southern Thailand in the later months of 2012 during regular raptor surveys. It upto 1,000 individuals had initially been reported in Kuala Gula, Perak State on 8 January 2013, with approximately 250 individuals reported in Batang Tiga, Melaka State the next day, and subsequently about 140 individuals in Muar, Johor State (Lim et al., 2011; Chuah, 2013). The presence of this species in Singapore, two weeks after the initial sightings in Perak, was suggestive of a fairly rapid, ongoing southward movement, the first time such a phenomenon has been documented along the Thai-Malaysian Peninsula (Low et al., 2013).

According to Roy and Sah (2013b), there were found temporal variation on the arrival of Asian open bills. They have observed in the 14 years continuous study that there is positive 
growth that was $65 \%$ in the Asian open bill stork population of the study area in the year 1989, when compared with the total number of these birds in 1985. But in the year 1993, there was negative growth in open bill population that is $45.89 \%$, when compared with the total number of their arrival in 1989 . But, there was positive growth of $42.82 \%$ in bird population in the study area in the year 1997, when compared with the total number of their arrival in 1993. There was again a positive growth of $81.66 \%$ in bird population of the study area in the year 2001, when compared with the total number of these species in 1997. In the year 2005, there was decline growth in bird population of $8.37 \%$ when compared with the total number of them in 2001. In the year 2009, there was a positive growth of $41.26 \%$ in comparison with the year 2005. It is amazing to note that there was also negative variation in the arrival of the birds, particularly in the years 1993 and 2005.

The negative trend in bird population is the result of flood by the river Kulik. In the year of flood hazard, the arrival of bird's evidenced massive negative trends, except these years, the area experienced very positive trends in the arrival of those birds. Climate change as witnessed worldwide has compelled several aquatic birds to migrate from adversely affected wetlands to other habitable wetlands for breeding (Cox, 2010). Apart from the flood, the changing climate, deforestation and anthropogenic factors are also responsible for decline in their arrival (Chen et al., 2011; Sekercioglu et al., 2012). Therefore, such analysis or approach of study does not only reveal the temporal qualitative change experienced by that habitat but also signify the impact of that on influx of bird population along with other species. Generally migratory birds are the key mobile links that contribute to the function of diverse ecosystem. This makes migratory birds prime witnesses to global climate and local environment change (Morrison, 1986; Wormworth and Sekercioglu, 2011). To know Asian open bill bird as an indicator of ecosystem health, further research work might be helpful in relation to human interference, physico-chemical properties of wetlands along with atmospheric condition and also trend of occurrence of this bird species seasonally within the park.

\section{CONCLUSIONS}

In conclusion, the present study reveals that occurrence of Asian open bill, Anastomus oscitans was observed highest population of 671 nos along the $300 \mathrm{~m}$ line transect area, which was a randomly selected study site at Nature park. As the present study was on the occurrence of Asian open bills inhabiting on the particular tree species viz. Ficus religiosa (Aswatha), Albizia lebbeck (Sirish), Anthocephalus indicus (Kadam), Terminalia arjuna (Arjun), Delonix regia (Gulmohor), Peltophorum pterocarpum (Yellow Flame Tree) and Dalbergia sisso (Seasom) at the study area Nature Park, Kolkata, India, which is similar with research works carried out by Roy and Sah (2013a and b). But the nest building was not observed in other 19 varieties of tree species such as Cocos nucifera (Coconut palm), Murraya koenigii (Curry tree), Azadirachta indica (Neem), Tectona grandis (Teak), Butea monosperma (Flame of the forest), Acacia auriculiformis (Earleaf acacia / Akashmoni), Gmelina Arborea (White teak/Gamar), Tamarindus indica (Tamarind), Ficus racemosa (Cluster fig/Dumur), Syzygium cumini (Black plum/Jamun), Pongamia pinnata (Indian Beech), Grewia asiatica (Falsa), Bombax malabaricum (Cotton), Alstonia scholaris (Chhatim), Leucaena leucocephala (Sababul) and four trees were as unidentified species.

As there is no previous study of this bird species on the nest building over specific tree species at this particular geographical area. Therefore, further research planning should be oriented considering the physico-chemical parameters as well as local atmospheric conditions 
along with human interaction as visitors in such a way, so that these barriers cannot affect nesting and breeding of those species as eco-indicator. Further relevant research is needed about the tree species preference, nest building and occurrence of the particular bird species in Nature park. These research might be an opening directed towards the conservation of these tree species to increase habitat of Asian open bill stork in the study area.

\section{Acknowledgement}

The authors thankfully acknowledge the help and support by the staff during tree survey and also help in tree identification especially by the gardener of the Mudiali Fishermen Cooperative Society (Nature Park), Kolkata, India.

\section{References}

[1] Ali S., Ripley S.D., Handbook of the Birds of India and Pakistan, Oxford University Press, New Delhi, (1978) 95-98.

[2] Blair R.B., Ecol Appl 9 (1999) 164-170.

[3] Chen I.C., Hill J.K., Ohlemüller R., Roy D.B., Thomas C.D., Science 333 (2011) 1024-1026.

[4] Chowdhury R., Sarkar S., Nandy A., Talapatra S.N., International Letters of Natural Sciences 11(2) (2014) 131-139.

[5] Chuah B.K., New Straits Times,. http://www.nst.com.my/nation/general (2013).

[6] Cody M.L., Physiological ecology. Academic Press (1985).

[7] Costanza R., d'Arge R., de Groot S., Farber M., Grasso B., Hannon B., Limburg S., O’Neil N.R., Paruelo J., Raskin R.G., Sutton P., Van den Belt M., Nature 387 (1997) 253-260.

[8] Cox G.W., Birds Migration and Global Change, Island Press, USA (2010).

[9] Dhua B., Mondal R. P., Dutta T. K., Int J Adv Res 1(9) (2013) 358-363.

[10] Grimmett R., Roberts T., Inskipp T., Helm Field Guides. Yale University Press (2001).

[11] Grimmett R., Inskipp C., Inskipp T., 1998. Birds of the Indian Subcontinent. Oxford University Press, 888 (1998).

[12] Hobson K.A., Rempel R., Recommendations for forest bird monitoring (2001).

[13] IUCN Version 2013.1, www.iucnredlist.org

[14] Johnson M., Ph.D. thesis, Osmania University, Hydrabad (1992).

[15] Lim K.C., Lim S.Y., Ooi B.Y., Asian openbill Anastomus oscitans in Chuping, Perlis. In: Malaysian Nature Society, Malaysia Bird Report 2008. Malaysian Nature Society, Kuala Lumpur (2011), pp. 26-27.

[16] Low B.W., Lim K.S., Yap F., Lee T.K., Lim K.C., Yong D.L., Nature in Singapore 6 (2013) 25-29.

[17] McClure H.E., Migration and Survival of the Birds of Asia. White Lotus Co., Ltd, Bangkok. (1998) 472 pp. 
[18] Mirza Z.B., EDRC, WWF - P (2007).

[19] Morrison M.L., Curr Ornithol 3 (1986) 429-451.

[20] Navarro A., Benítez H., El dominio del aire. La Ciencia desde México (138), Fondo de Cultura Económica, México, D.F. [Navarro A., Benitez H., Mastering Air. 216. Science from Mexico, Fondo de Cultura Economica Sepconacyt (1995) 138 pp].

[21] Newton I., J Anim Ecol 64 (1995) 675-696.

[22] Orians G.H., Lowenthal D., Meaning and values in landscape (1986).

[23] Padoa-Schioppa E., Baietto M., Massa R., Bottoni L., Ecological Indicators 6 (1) (2006) 83-93.

[24] Robson C., A Field Guide to the Birds of South-East Asia. New Holland Publishers Ltd, UK. (2000) 504 pp.

[25] Roy P.B., Sah R., J Environ Sci Toxicol Food Tech 4 (2) (2013a) 18-23.

[26] Roy P.B., Sah R., Int Res J Environ Sci 2(4) (2013b) 39-43.

[27] Safford R. J., Maltby T.T.E., Duong V.N., Tropical Biodiversity 5 (1998) 217-244.

[28] Sakoot T., (2012) Unusual tourists land in Phuket, The Phuket News, (2012) http://www.thephuketnews.com/unusual-tourists-land-in-phuket-35520.php

[29] Sanesi G., Chiarello F., Urban Forestry Urban Greening 4 (2006)125-134.

[30] Sekercioglu C.H., Primack R.B., Wormworth J., Biological Conservation 148 (2012) $1-18$.

[31] Sidra S., Ali Z., Chaudhry M.N., Pakistan J Zool 45(4) (2013) 1069-1082.

[32] Sun Visal., Allebone-Webb S., Monitoring of large waterbirds at Prek Toal, Tonle Sap Great Lake, In: Biodiversity Monitoring in the Floodplain of the Tonle Sap in 20082009. Wildlife Conservation Society Cambodia Program, Phnom Penh (2009), pp. 1-19.

[33] Tanveer A., Shahzad M., Chaudhry A.A., Punjab Univ J Zool 17 (2002) 35-51.

[34] Tiwary V.M., Joy of bird watching 1st Ed (2002) 1-287.

[35] Turner W.R., Landscape Urban Planning 65 (2002) 149-166.

[36] Wells D.R., The Birds of the Thai-Malay Peninsula Vol. 1, Academic Press, UK. (1999) $600 \mathrm{pp}$.

[37] Wetlands International, Waterbirds population estimates. 3rd ed. Wageningen, The Netherlands: Wetlands International (2002).

[38] Wormworth J., Sekercioglu C.H., Winged sentinels birds and climate change, Cambridge University Press, NewYork (2011). 